\title{
Formation of ring marks in stocked tilapia juveniles (Oreochromis aureus/O. niloticus) (Perciformes: Cichlidae)
}

\author{
Ana L. Ibañez ${ }^{1} \&$ Marco A. Romo-Coronel ${ }^{1}$ \\ 1 Universidad Autónoma Metropolitana-Iztapalapa, Av. San Rafael Atlixco 186, Col. Vicentina, 09340 México D.F., \\ México; ana@xanum.uam.mx. Phone: +52 (55) 5804-6585, Fax: +52 (55) 5804-4738.
}

Received 05-VII-2006. Corrected 23-II-2007. Accepted 07-V-2007.

\begin{abstract}
Lake Metztitlán was dried up completely in the spring of 1998 and refilled in August of that year. In the period September-November, two cohorts of 1.6 million juveniles of a tilapia hybrid were stocked (Oreochromis aureus/O. niloticus), and monitored every month for one year. Since the date of birth of these juveniles was known, the analyses focused on whether the ring marks of the scales, sagittae and opercula or the circuli of the scales could be used to age them. The ring marks of the scales and opercula showed great variability, and the sagittae had a significant relationship with length, but it is unclear if at least the first ring mark could be formed at the hatchery and reflect changes in diet and/or tank movements in the fish farm. The circuli had a continuous regular behavior, with a formation rate of $10.38 \pm 0.93$ and $11.38 \pm 0.95 \mathrm{circuli} / \mathrm{month}$ for the first and second cohorts, respectively. This proportion was maintained during the study period, and could be of help to calculate an approximate age of juveniles, especially in stocked fish that show multiple ring marks because of manipulation in fish farms and stocking events. Rev. Biol. Trop. 55 (3-4): 1005-1013. Epub 2007 December, 28.
\end{abstract}

Key words: Oreochromis, age, stockings, otoliths, fish scales, annuli, circuli.

To the fisheries biologist, otoliths, fish scales and hard structures in general are important tools in the understanding of the life of fish and fish populations. Contrary to temperate areas where annuli are formed each year, the ring marks of otoliths or scales in tropical wild tilapia populations show wide variability. Ring marks could be formed once during the dry summer period (Booth et al. 1995, Booth and Merron 1996, Gómez-Márquez 1998) or during winter (Weyl and Hecht 1998), or two times because of a temperature reduction, drying up of water bodies or sexual maturation (Guzmán 1994, Admassu and Casselman 2000, JiménezBadillo 2004). Moreover, when these species are subject to stocking, several ring marks can be formed at the farm due to changes in diet, movements between tanks or stress (Britton et al. 2004). This could lead to confusion between ring mark formation due to natural causes and those due to stocking events. This drive us to look ahead and search for structures that can help in the ageing process of this species.

Tilapia rendalli (Boulenger), Oreochromis mossambicus (Peters) and $O$. aureus (Steindachner) were first introduced to Mexico (Temascal, Oaxaca) in 1964 by Auburn University, Alabama. They became widely distributed throughout natural and artificial water reservoirs in both tropical and temperate regions of the country. Although they were initially introduced indiscriminately to large basins, after 20 years they have spread to numerous smaller water bodies and have become the most important fisheries species in Mexican continental waters. Lake Metztitlán, with 640 ha, has received continuous stocking of the hybrid $O$. aureus/O. niloticus (Linne), for at least 15 years, and now supports $95 \%$ of the total local catch. The average production in 
this lake has been high in the last ten years (370 $\mathrm{kg} / \mathrm{ha} / \mathrm{yr}$ ) and is supported by stocking because over fishing is a constant problem in the area (Ibáñez 2004). Recently some studies have been carried out in the lake; Barriga-Sosa et al. (2004) studied the morphometric, meristic and genetic characters of Metztitlán's tilapia and Ibáñez (2004) reported on the importance of the timing of stocking events of tilapia juveniles in Lake Metztilán.

Lake Metztitlán dried up completely in the spring of 1998 and refilled in August of the same year. This event offered the opportunity to follow two different stocking events and to test whether the ring marks of scales, sagittae and operculum, and the circuli of scales could be used to age the juvenile hybrid of Oreochromis aureus/O. niloticus.

\section{MATERIALS AND METHODS}

All stock materials were obtained from the same crosses $O$. aureus/O. niloticus but were stocked at different times. The first stocking of tilapia juveniles took place on September $18^{\text {th }}$ and $23^{\text {rd }}$ (first cohort consisted of 931000 juveniles), and the second occured on October $30^{\text {th }}$ and November $6^{\text {th }}, 1998$ (second cohort consisted of 682000 juveniles). It is important to note that, for the purpose of this study, the individuals introduced in two close consecutive stocking events were considered as one cohort, as the stocking events took place within a short interval of time ( 5 and 6 days for the first and second cohort, respectively). The fish's size at stocking time was between 35 and $75 \mathrm{~mm}$ (22.5 months old).

Tilapia juveniles were sampled monthly during 12 months at Lake Metztitlán (20 40'$20^{\circ} 42^{\prime} \mathrm{N}$, and 98 $51^{\prime}-98^{\circ} 53^{\prime} \mathrm{W}$ ) between September 1998 and September 1999, with the exception of October 1998 and July 1999. Sampling was done with a $30 \mathrm{~m}$ long, $1.5 \mathrm{~m}$ high and $1.5 \mathrm{~cm}$ knot-to-knot mesh size trawl net. Each sampling event consisted of four trawling operations at two stations located at the mouth of the Venado River and at the western edge of the lake, respectively. Captured organisms ( $\mathrm{n}=209$ between 48 and $283 \mathrm{~mm}$ of total length $=\mathrm{TL}$ ) were measured to nearest $0.1 \mathrm{~mm}$. The size of first maturity was 200-210 and 202$219 \mathrm{~mm}$ for females and males, respectively (Ibáñez et al. 2002), so fish larger than 200 $\mathrm{mm}$ were not included in the analysis in order to avoid the variability normally due to sexual maturation.

One hundred and ninety two (192) pairs of sagittae were extracted, the left otoliths were weighted (to nearest $0.0001 \mathrm{~g}$ ), sectioned and prepared for examination as Secor et al. (1991) recommended. One hundred and fifty two pairs of opercula were collected, washed with tap water, dried and labeled. An average of 10 scales from the posterior part of the operculum were collected from each of the organisms, four of them were read using light transmitted by a Leitz Wetzlar projector using a 2.5/0.08 objective. Readings of the number of ring marks (RM) and number of circuli $(\mathrm{CN})$ in scales were done by four observers. For the $\mathrm{CN}$ determination, the average percent error (APE) (recommended by Beamish and Fournier 1981), the coefficient of variation (CV) and the precision index (D) were estimated in order to examine the precision of the four readers (Chang 1982), each one having read the same four scales per fish. In addition, an ANOVA was used to analyze the differences between the scales of each fish and each reader. The correlation coefficients (r) between readers were estimated and plotted. The relationship between the total length (TL) and time was estimated for the two cohorts together and also for each separate cohort. Ibáñez (2004) used the Kernel density estimators (KDEs) to separate the two cohorts according to total length. The average length of each cohort was plotted against time.

The daily and monthly $\mathrm{CN}$ formation was estimated per cohort, using the determination of the more precise reader and assuming that the juveniles were two months old when they were stocked into the lake. All reported test statistics were considered significant if $\mathrm{p}<0.05$. 


\section{RESULTS}

As was the case with the opercula, the scales' ring marks did not show any relationship with the TL (Fig. 1). In $74 \%$ of the opercula the RM were incomplete, so they were also unable to provide information relative to the age of the organisms.

The result of the relationship between length and RM of the sagittae (Fig. 2) showed a highly lineal relationship, nevertheless, the length variability of the RM was wide. Table 1 shows the monthly frequency of RM obtained with the otolith determination. The September 1998 sample showed between one and two RM (Table 1). A transition from RM one to RM two could be formed in September 1998, and possibly a transition from RM two to RM three started in June-August 1999. September of 1999 was eliminated from this analysis because there were only fish over $200 \mathrm{~mm}$ with four RM. The relationship between TL and otolith weight (Fig. 3) shows an allometric relationship with more variability in length after sexual maturation, at around $200 \mathrm{~mm}$.

The plots of $\mathrm{CN}$ for each reader depicted low correlation values between readers 1-3 and reader 4 (Fig. 4D-F), in addition reader

TABLE 1

Ring marks determined monthly from the determination of sectioned otoliths

\section{Rings Mark (RM) frequency}

$\begin{array}{lccccc}\text { Month } & \mathrm{n} & 1 & 2 & 3 & 4 \\ \text { Sep-98 } & 8 & 5 & 3 & 0 & 0 \\ \text { Nov } & 21 & 5 & 11 & 5 & 0 \\ \text { Dic } & 10 & 1 & 8 & 1 & 0 \\ \text { Jan-99 } & 13 & 0 & 12 & 1 & 0 \\ \text { Feb } & 4 & 2 & 1 & 1 & 0 \\ \text { Mar } & 9 & 0 & 9 & 0 & 0 \\ \text { Abr } & 11 & 1 & 9 & 1 & 0 \\ \text { May } & 15 & 0 & 12 & 2 & 1 \\ \text { Jun } & 19 & 0 & 11 & 5 & 3 \\ \text { Ag } & 8 & 0 & 2 & 6 & 0\end{array}$

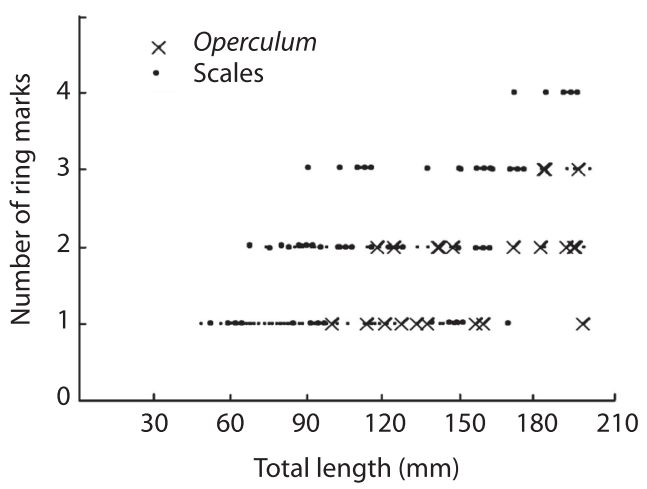

Fig. 1. Relationship between TL (mm) and number of ring marks (RM) of scales and operculum.

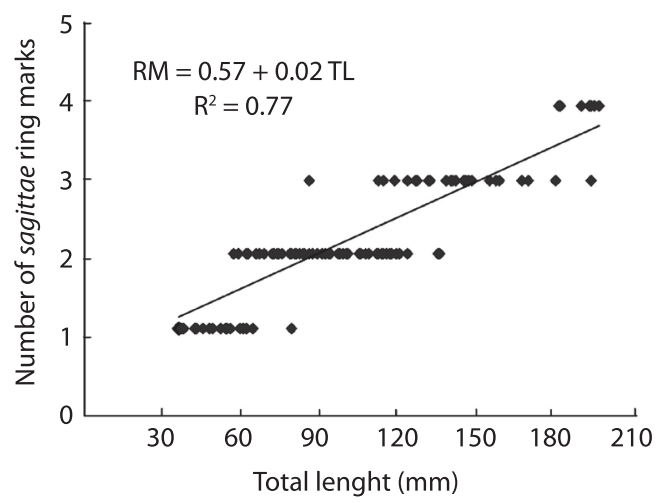

Fig. 2. Relationship between TL ( $\mathrm{mm}$ ) and number of ring marks (RM) of sagittae.

4 showed the highest levels of imprecision (Table 2). Readers 1 and 3 depicted a very high correlation index (Fig. 4B) nevertheless the imprecision of those readers was high. Reader 2 showed the lowest imprecision and high correlation index with readers 1 and 3 (Fig. 4A and $\mathrm{C}$ ). The ANOVA did not show significant differences between the four scale readings nor between the observers.

Fig. 5 shows the $\mathrm{CN}$ of the reader 2 in relation to the TL of the organisms. This regression was highly significant as it was the relationship between the observed and predicted data with a high value of adjustment $\left(\mathrm{R}^{2}=0.87\right)$.

The relationship between time and TL for the fish of the two cohorts plotted together is shown in Fig. 6A, while Fig. 6B depicted 


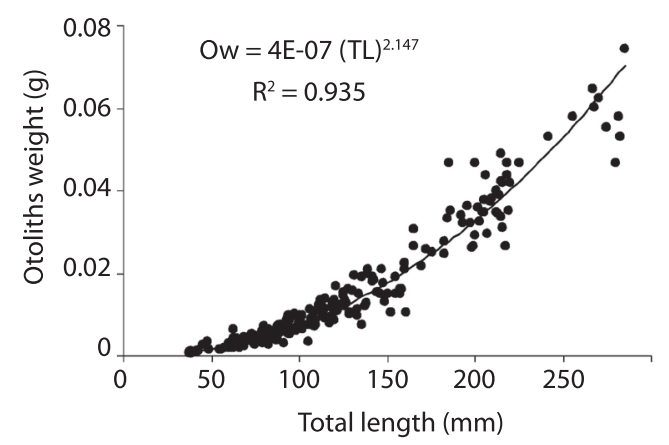

Fig. 3. Relationship between TL (mm) and otolith weight (mg).

the same relationship for the cohorts plotted separately. There is an improvement in fitness when the cohorts are plotted separately instead of together; this becomes more notable when the averages of the Gaussian components are used (Fig. 6C).

Fig. 7 shows the relationship between the numbers of circuli and time, for the two cohorts

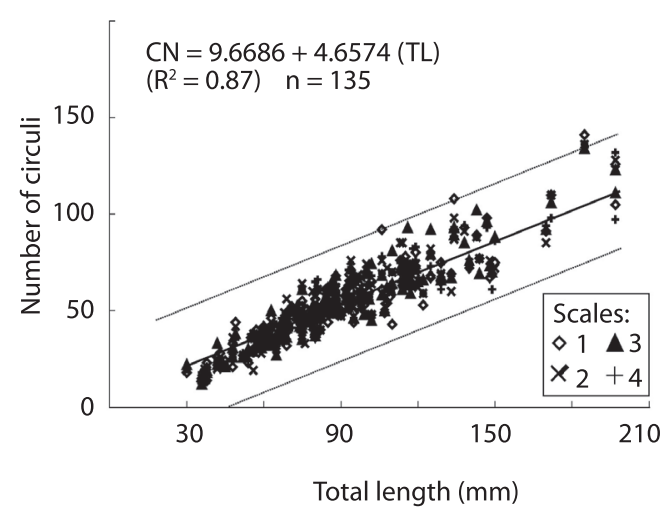

Fig. 5. Relationship between TL ( $\mathrm{mm})$ and number of circuli of the reader 2. Scales: $1(\diamond) ; 2(x) ; 3(\boldsymbol{\Delta})$ and $4(+)$. The dashed lines are upper and lower $95 \%$ confidences levels.

introduced to the lake. Because the age of the fish was known, the average circuli formed in time (Table 3) was $10.38 \pm 0.93$ circuli/month for the first cohort and $11.38 \pm 0.95$ circuli/ month for the second cohort. In the first cohort, circuli formation was more homogenous with

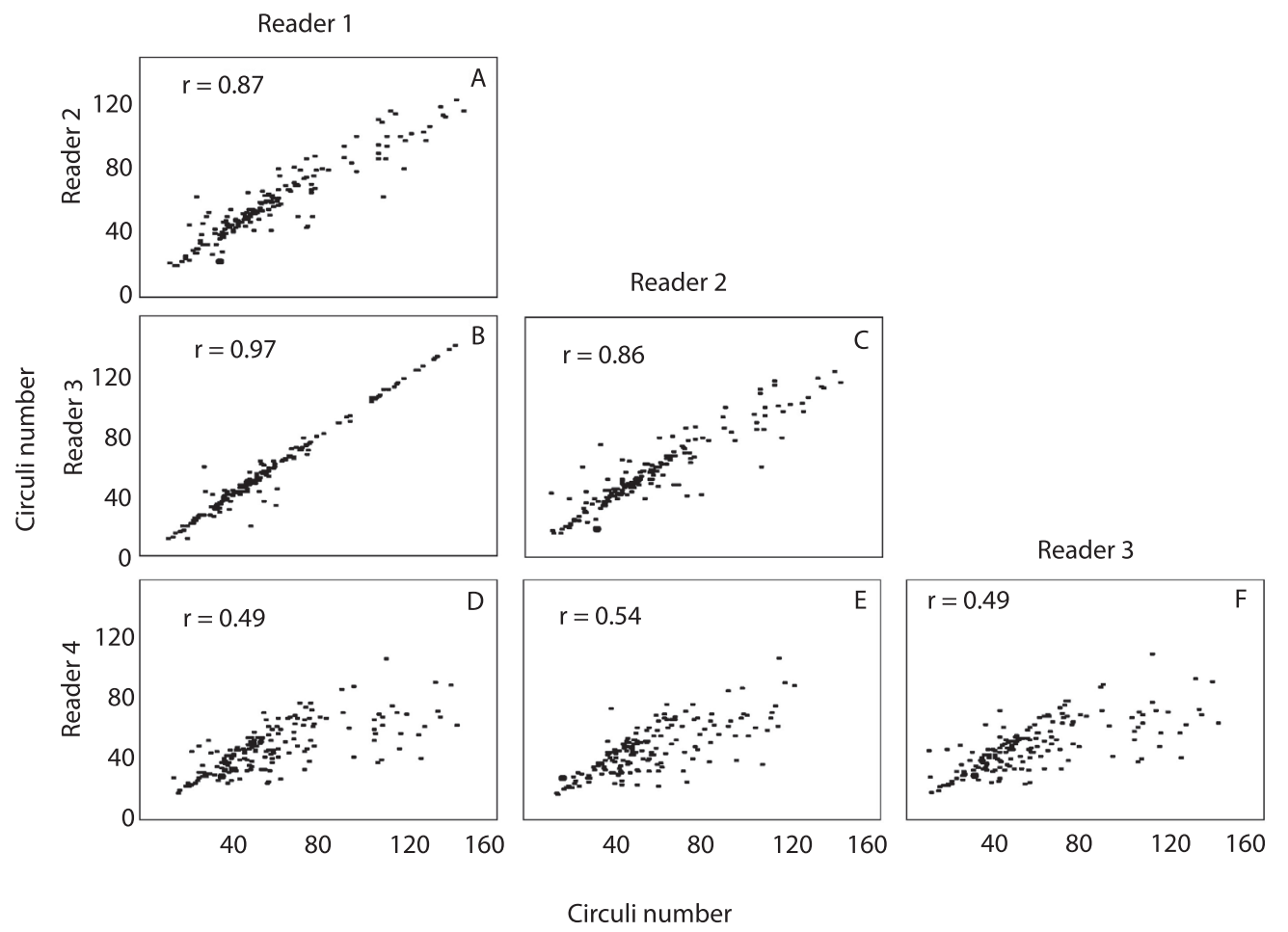

Fig. 4. Correlation of $\mathrm{CN}$ determinations among readers. Correlation coefficient (r). 
TABLE 2

Measures of precision for comparing the circuli number scale determinations by reader

$\begin{array}{cccc}\text { Reader } & \begin{array}{c}\text { Average } \\ \text { percent error } \\ (\text { APE })\end{array} & \begin{array}{c}\text { Coefficient } \\ \text { of variation }(\%)^{\mathrm{b}}\end{array} & \begin{array}{c}\text { Index of } \\ \text { precision }(\%)\end{array} \\ 1 & 9.06 & (\mathrm{CV}) & (\mathrm{D}) \\ 2 & 6.62 & 12.23 & 6.12 \\ 3 & 8.54 & 8.91 & 4.46 \\ 4 & 9.70 & 11.45 & 5.72 \\ & & 12.79 & 6.40\end{array}$

a. From Beamish and Fournier (1981); ${ }^{b}$ From Chang (1982)
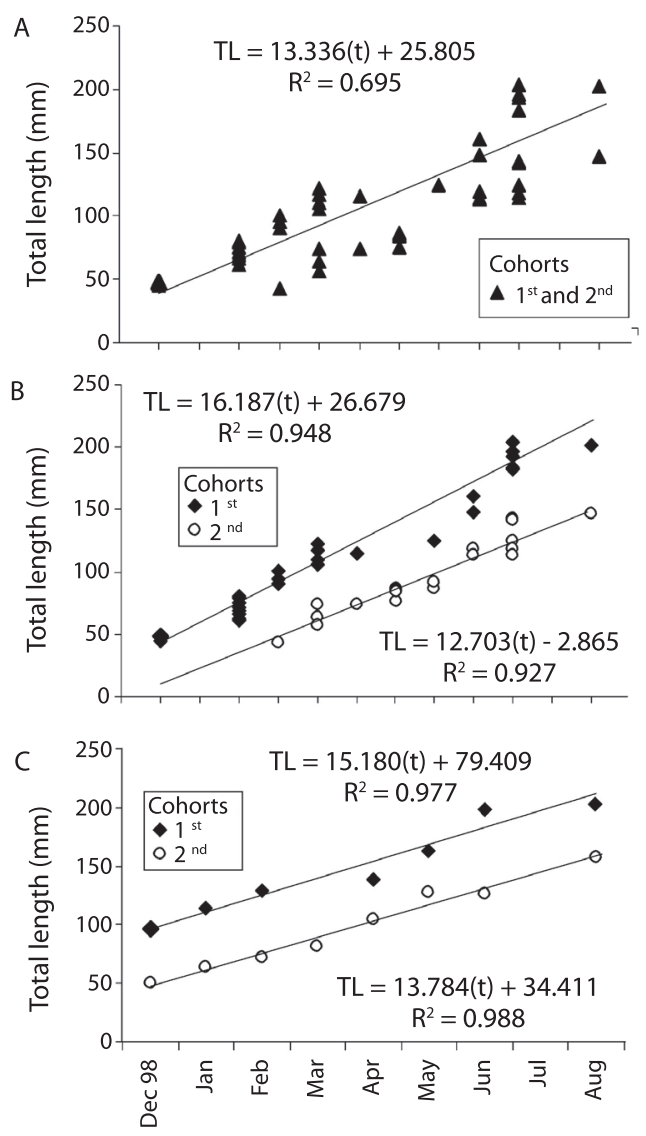

Time (months)

Fig. 6. Relationship between time and total length; A. for the two cohorts together; B. for each cohort separately; C. for each cohort separately with the average of each Gaussian component by cohort from Ibáñez (2004).

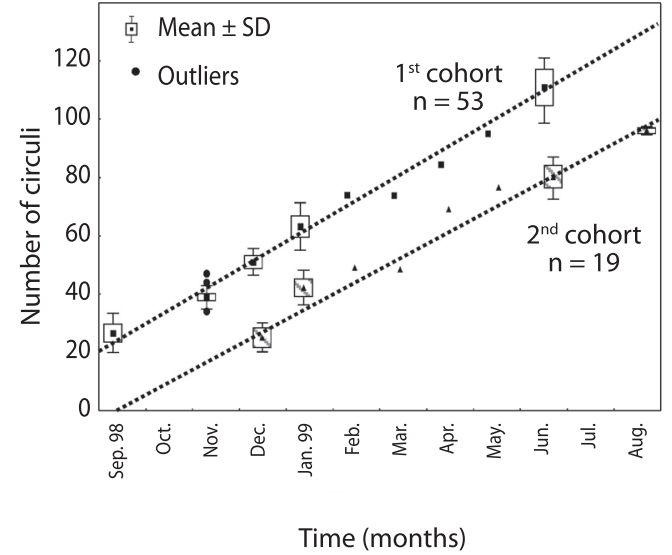

Fig. 7. Boxplot of number of circuli through time from September 1998 to August 1999 for the first and second cohort of tilapia.

slightly lower variance; this was possibly due to the size of the sample.

\section{DISCUSSION}

The RM of the opercula and scales were relatively of small use due to the difficulty in their identification. In the scales, the RM were very thin, and in both structures the RM were incomplete.

The RM in the sectioned otoliths were easy to interpret but they showed great length variability, especially for the second and third 
TABLE 3

Mean number of circuli through time for the $1^{\text {st }}$ and $2^{\text {nd }}$ cohort

\begin{tabular}{lcccccc} 
Time & \multicolumn{3}{c}{$1^{\text {st }}$ cohort } & \multicolumn{3}{c}{$2^{\text {nd }}$ cohort } \\
(days) & Num circuli & Circuli/day & Circuli/month & Num circuli & Circuli/day & Circuli/month \\
60 & 19 & 0.32 & 9.50 & 21 & 0.35 & 10.50 \\
90 & 27 & 0.30 & 9.00 & 39 & 0.35 & 10.50 \\
120 & 44 & 0.37 & 11.00 & 44 & 0.43 & 13.00 \\
150 & 57 & 0.38 & 11.40 & 59 & 0.37 & 11.00 \\
180 & 64 & 0.36 & 10.67 & 69 & 0.39 & 11.80 \\
210 & 75 & 0.36 & 10.71 & 78 & 0.38 & 11.50 \\
Mean \pm SD & & & $10.38 \pm 0.93$ & & & $11.38 \pm 0.95$
\end{tabular}

RM. The first and second RM could be formed at the fish farm due to the hatchery, a change in supplied diet, movements from tanks and/or stress. These events have been shown to cause $\mathrm{RM}$ in cyprinids by Britton et al. (2004). It was not possible in this study to distinguish between hatchery marks and the first RM. A further RM could be formed during the stocking event of September and November of 1998. Additionally, an RM could be caused by the change between the lowered lake level of the spring dry season and the beginning of the rain season in June-August. Probably the last mark was due to sexual maturation. There is evidence of sagittae checks in female of $O$. niloticus when gametogenesis begins (Massou et al. 2004). Otolith weight in this study showed an inflexion point between 184 and $200 \mathrm{~mm}$ of TL, which seems to coincide with the length of sexual maturation of the tilapias. Morison et al. (1998) mentioned an inflexion point in otolith weight at around the age of maturity.

Despite the proven value of previous age determination studies of tilapia species using otoliths (Booth et al. 1995, Booth and Merron 1996, Weyl and Hecht 1998, Admassu and Casselman 2000) opercula (Jiménez-Badillo 2004) and annuli in scales (Moreau 1971, Wosnitza-Mendo 1980, Yamaguchi et al. 1990), these studies were performed on fish from the wild. Those individuals did not experience as many environmental changes as stocked fish generally do, where at least two RM could be due to a combination of hatching, farm movements and stocking events. Because of the uncertainties of RM formation in stocked fish, the results are inconclusive.

The low correlation between time and length when using all the specimens together, suggest the presence of more than one cohort; the subsequent separation using Kernel Gaussian components (Fig. 6C) showed that a better fit was achieved by the separation of the data into two distinct modes, from which two cohorts emerged. The use of KDEs to estimate the size frequency distributions made it possible to distinguish the modes with clarity, which is difficult to attain using other methods. The Gaussian variable adjusts the bandwidth in accordance to the number of observations showing more details and a greater separation of the modes in comparison with fixed band estimators (Salgado-Ugarte et al. 1993). These characteristics of the KDE allow the recognition of cohorts with few differences in length, especially for the youngest fish.

The ANOVA could not detect the difference in the $\mathrm{CN}$ determination between readers despite the difference between the four readers being remarkable. The precision measures, APE, CV and D clearly showed the differences between the four readers. This was used to select the precise and accurate data. Therefore, the ability to evaluate the quality of the readings 
is an indispensable tool in age analysis (Chang 1982, Campana et al. 1995).

It has been shown that the daily deposition of weakfish Cynoscion regalis (Bloch and Schneider) scale circuli occurred over a size range, approximately 14.3 to $111.9 \mathrm{~mm}$ standard length (Szeldlmayer et al. 1991). Also Lai et al. (1996: 85) mentioned that Werder (1984) studied the scales of juvenile Brycon melanopterus (Howes 1982) and found that circuli formation revealed a 2-day rhythm. Bhatia (1931) studied the scales from the early stages of a large number of specimens of rainbow trout, which were all obtained from the same spawn, and found that when the fish were fed uniformly throughout a year, all the circuli were homogeneously deposited. Gray and Setna (1931) found that food was the primary factor influencing circuli spacing in brown trout. In addition, Bilton and Robins (1971) fed young sockeye salmon during a two month period at three food levels and constant photoperiod (12/12 h light/dark) and they concluded that circuli spacing was sensitive to changes in feeding. Shackell and Doyle (1991) showed that the diet regime in $O$. niloticus had a significant effect on growth and circuli spacing. Since it is known that constant food supply produces a constant circuli formation, it can be assumed that the juveniles mentioned above of C. regalis and B. melanopterus, were found in sheltered habitats within estuaries and water bodies characterized by abundant food. Additionally, the tilapias of this study had abundant detritus due to the decomposing grass, which grew during the period of desiccation of the lake, which occurred between spring and the rain season in August of 1988.

The circuli formation could be used in fish analysis in two complementary ways. Firstly, circuli could be used as a growth estimator; circuli formation rate is modified with active fish growth (Beamish and McFarlane 1983, Fukuwaka 1998, Fisher and Pearcy 2005), which in turn is influenced by parameters such as temperature (Arai and Sakamoto 1995). Secondly, circuli formation can be used as a practical estimation of age, as long as the deposition is continuous. The relationship found in this study shows regularity in $\mathrm{CN}$ appearance, with 10 and 11 per month for cohort one and two, respectively. This rate of deposition was maintained during the whole of the juvenile stage and could be of help in calculating an approximate age of juveniles, especially of stocked fish because they show many ring marks due to manipulation in fish farms. There are few studies linking time and circuli formation, so additional research is required to further clarify the limits of growth and age in circuli deposition.

\section{ACKNOWLEDGMENTS}

We thank Juan Juárez Flores for his help in the determination of the circuli, and José Luis García Calderón for his field help. We thank Joanne Phillips who kindly reviewed the English version.

\section{RESUMEN}

El lago de Metztitlán se secó completamente en la primavera de 1998, inundándose nuevamente en agosto del mismo año para ser repoblado entre septiembre y noviembre con 1.6 millones de jóvenes de un híbrido de tilapia (Oreochromis aureus/O. niloticus) en dos periodos. Ambas cohortes fueron monitoreadas mensualmente durante un año. Debido a que la fecha de nacimiento era conocida, el objetivo del estudio fue evaluar si las marcas anulares de las escamas, las sagittae y los opérculos, o los circuli de las escamas pueden usarse para estimar la edad. Los anillos de las escamas y opérculos mostraron gran variabilidad, mientras que las de las sagittae se relacionaron significativamente con la longitud, sin embargo no quedó claro si al menos el primer anillo podría haber sido formado por cambios en dieta o movimientos en los tanques de la granja de cultivo. Por el contrario los circuli mostraron una formación regular con una tasa de formación de $10.38 \pm 0.93$ y $11.38 \pm 0.95 \mathrm{circuli} / \mathrm{mes}$ para la primera y segunda cohortes, respectivamente, proporción que fue mantenida durante el periodo de estudio y que puede ser usada para calcular la edad de los jóvenes, especialmente en organismos que muestran numerosos anillos debido a la manipulación sufrida en las granjas o debido a las "siembras".

Palabras clave: Oreochromis, edad, repoblamientos, otolitos, escamas, annuli, circuli. 


\section{REFERENCES}

Admassu, D. \& J.M. Casselman. 2000. Otolith age determination for adult tilapia, Oreochromis niloticus L. from Lake Awassa (Ethiopian Rift Valley) by interpreting biannuli and differentiating biannual recruitment. Hydrobiologia 418: 15-24.

Arai, N. \& W. Sakamoto. 1995. Effects of seawater temperature on scales circuli deposition of reared red-sea bream. Nippon Suisan Gakk. 61: 316-319.

Barriga-Sosa, I.A., M.D.L. Jiménez-Badillo, A.L. IbáñezAguirre \& J.L. Arredondo-Figueroa. 2004. Variability of tilapias (Oreochromis spp.) introduced in Mexico: morphometric, meristic and genetic characters. J. Appl. Ichtiol. 20: 7-14.

Beamish, R.J. \& D.A. Fournier. 1981. A method for comparing the precision of a set of age determinations. Can. J. Fish. Aquat. Sci. 38: 982-983.

Beamish, R.J. \& G.A. McFarlane. 1983. Validation of age determination estimates: the forgotten requirement. T. Am. Fish. Soc. 112: 735-743.

Bhatia, D. 1931. On production of annual zones in the scales of rainbow trout (Salmo irideus) I.J. Exp. Zool. 59: 45-49.

Bilton, H.T. \& G.L Robins. 1971. Effects of feeding level on circulus formation on scales of young sockeye salmon (Oncorhynchus nerka). J. Fish. Res. Board Can. 28: 861-868.

Booth, A.J., Merron G.S. \& C.D. Buxton. 1995. The growth of Oreochromis andersonii (Pisces: Cichlidae) from the Okavango Delta, Botswana, and a comparison of the scale and otolith methods of ageing. Environ. Biol. Fish. 43: 171-178.

Booth, A.J. \& G.S. Merron. 1996. The age and growth of the greenhead tilapia Oreochromis macrochir (Pisces: Cichlidae) from the Okavango Delta, Botswana. Hydrobiologia 321: 29-34.

Britton, J.R., I.G. Cowx \& G. Peirson. 2004. Sources of error in the ageing of stocked cyprinids. Fisheries Manag. Ecol. 11: 415-417.

Campana, S.E., M.C. Annand \& J.I. McMillan. 1995. Graphical and statistical methods for determining the consistency of age determinations. T. Am. Fish. Soc. 124:131-138.
Chang, W.Y.B. 1982. A statistical method for evaluating the reproducibility of age determination. Can. J. Fish. Aquat. Sci. 39: 1208-1210.

Fisher, J.P. \& W.G. Pearcy. 2005. Seasonal changes in growth of coho salmon off Oregon and Washington and concurrent changes in the spacing of scale circuli. Fish. B-NOAA 103: 34-51.

Fukuwaka, M.A. 1998. Scale and otolith patterns prove growth history of Pacific salmon. North Pacific Anadromous Fisheries Commercial Bulletin 1: 190198.

Gómez-Márquez, J.L. 1998. Age and growth of Oreochromis niloticus (Perciformes: Cichlidae) in Mexico. Rev. Biol. Trop. 46: 929-936.

Gray, J. \& S.B Setna. 1931. The growth of fish. IV. The effects of food supply on the scales of Salmo irideus. J. Exp. Biol. 8: 55-62.

Guzmán, U.A. 1994. Parámetros biológicos de tilapia (Oreochromis aureus, Steindachner, 1864) de la presa Adolfo López Mateos “El Infiernillo”, MichoacánGuerrero, México. Tesis de licenciatura, Facultad de Ciencias, Universidad Nacional Autónoma de México. México D.F., México.

Ibáñez, A.L., J.L. García-Calderón \& A. Perez-Rojas. 2002. Análisis del repoblamiento de Oreochromis spp. a través del estudio limnológico-pesquero del lago de Metztitlán, Hidalgo. Informe final, Universidad Autónoma Metropolitana, México D.F., México.

Ibáñez, A.L. 2004. Impact of the timing of stocking on growth and allometric index in aquaculture-based fisheries. Fisheries Manag. Ecol. 11: 81-87.

Jiménez-Badillo, L. 2004. Application of holistic and analytical models for the management of tilapia fisheries in reservoirs. Hidrobiológica 14: 61-68.

Lai, H-L., V.F. Gallucci, D.R. Gunderson \& R.F. Donnelly. 1996. Age determination in fisheries: methods and applications to stock assessment, p. 82-178. In V.F. Gallucci, S.B Saila, D.J. Gustafson \& B.J. Rothschild (eds.). Stock assessment: quantitative methods and applications for small-scale fisheries. Lewis, Boca Raton, Florida, USA.

Massou, A.M., J. Panfili, P.Y. Le Bail, R. Lae, O. Mikolasek, G. Fontenelle \& J.F. Baroiller. 2004. Evidence of perturbations induced by reproduction 
on somatic growth and microincrement deposition in Oreochromis niloticus otoliths. J. Fish Biol. 64: 380-398.

Moreau, J. 1971. Comparative biology of Tilapia rendalli (Boulenger) (Pisces Cichlidae) in Lake Itasy and lake Mantasoa, (in French). Cah. Orstom Hydrobiol. 5: 3-52.

Morison, A.K., S.G. Robertson, \& D.C. Smith. 1998. An integrated system for production fish ageing: image analysis and quality assurance. N. Am. J. Fish. Manag. 18: 587-598.

Salgado-Ugarte, I.H, M. Shimizu \& T. Taniuchi. 1993 Exploring the shape of univariate data using kernel density estimators. Stata Tech. Bull. 16: 8-19.

Secor, D.H., J.M. Dean \& E.H. Laban. 1991. Manual for otolith removal and preparation for microstructural examination. Technical Publication Num. 1991-01. Belle W. Baruch Institute for marine Biology and Coastal Research. University of South Carolina, California, USA.

Shackell, N.L. \& R.W. Doyle. 1991. Scale morphology as an index of developmental stability and stress resistance of tilapia (Oreochromis niloticus). Can. J. Fish. Aquat. Sci. 48: 1662-1669.

Szedlmayer, S.T., K.W. Able, J.A. Musick \& M.P. Weinstein. 1991. Are scale circuli deposited daily in juvenile weakfish, Cynoscion-regalis. Environ. Biol. Fish. 31: 87-94.

Werder, U. 1984. Age determination by scale analysis in juvenile Matrincha (Brycon cf. melanopterus Mueller and Troschel, Teleostei: Characoidei), a tropical characin from the central Amazon. Anim. Res. Develop. 19: 48-66.

Wosnitza-Mendo, C. 1980. Population dynamics and ecology of Tilapia rendalli (Blgr.) in Lago Sauce (Peru). Berichte aus dem Institut für Meereskunde an der Christian-Albrechts-Universität Kiel. Kiel 79: 1-128.

Weyl, O.L.F. \& T. Hecht. 1998. The biology of Tilapia rendalli and Oreochromis mossambicus (Pisces: Cichlidae) in a subtropical lake in Mozambique. S. Afr.J. Zool. 33: 178-188.

Yamaguchi, Y., N. Hirayama, A. Koike \& A.A. Hussein. 1990. Age determination and growth of Oreochromis niloticus and Sarotherodon galilaeus in High Dam Lake, Egypt. B. Jpn. Soc. Sci. Fish. 56: 437-443. 
